\title{
SELECTED ISSUES REGARDING THE IMPLEMENTATION OF CSR IN POLISH AGRIBUSINESS ENTERPRISES: CASE STUDY
}

Marcin Ratajczak ${ }^{1}, \mathrm{PhD}$; Tomasz Rokicki², PhD, habil.

1,2 Warsaw University of Life Sciences

\begin{abstract}
The purpose of this elaboration is the presentation of selected issues related to the implementation of CSR in agribusiness enterprises from rural areas of the Mazowieckie voivodeship. Research on the opinion of entrepreneurs on the concept of CSR, its scope and application of the principles of social responsibility were carried out at the turn of 2017 and 2018 and included 325 micro (0-9 people), small (10-49 employees) and medium (50-249 employees) agribusiness enterprises conducting economic activity in rural areas of the Mazowieckie voivodeship. The research was carried out by means of a diagnostic survey, and the basic research tool was an electronic questionnaire that was sent to the surveyed entities. The survey was sent to all agribusiness entities operating in the studied voivodeship - 325 questionnaires were fully and correctly completed. The material obtained in this way was subjected to mathematical - statistical analysis. The arithmetic mean, independence test $\mathrm{x} 2$, Chuprov convergence coefficient and $\mathrm{C}$. Pearson coefficient (corrected and regular) were used. Social responsibility in the organizational structure of the surveyed companies was hardly visible because there were no people responsible for developing the CSR concept related to the subject of the activity and the specificity of the company. Only every third respondent stated that actions were being taken for the benefit of broadly understood environment and they were inscribed in the company's business strategy.
\end{abstract}

Key words: SME, agribusiness, corporate social responsibility, rural areas, strategy.

JEL code: $012,013,018$

\section{Introduction}

Corporate social responsibility (CSR) is a concept, according to which enterprise at the stage of strategy building voluntarily takes into account social interests and environmental protection, as well as relations with their stakeholders (Ratajczak, Woloszyn, Stawicka 2012). Nowadays, more and more attention is paid to the fact that corporate social responsibility is of strategic and dynamic character and is based on constant (continuous) improvement, as well as cooperation with all stakeholders of the company (Carroll, 1974).

Therefore, the importance of CSR in management science becomes more and more crucial. In the economic practice, on the other hand, it generates a dialogue process, learning mutual expectations and opportunities, close monitoring and improving strategies within a broadly understood partnership (Willard, 2002).

Social responsibility is also defined as a moral and lawful duty towards the entire environment, both internal and external to the enterprise - the social responsibility of the company means that it is morally responsible and obliged to account for the law and society from its activities. It is responsible towards the owners, clients, employees, shareholders, creditors, ecological movements, suppliers, cooperators, banks and state administration (Vogel, 2005; Garriga, Mele, 2004).

It is also necessary to pay attention to the fact that CSR leads to building a competitive advantage strategy, based on providing long-lasting value for both shareholders and other partners-stakeholders, especially those important in the agribusiness sector (Gasparski, 2004; Waddock, 2008; Madra-Sawicka, 2016; Wysokinski, Dziwulski, 2013).

It should be stated that social responsibility should be taken into account both inside and outside the enterprise, as the basis of business, and not as additional actions and ethical procedures undertaken in selected areas and activities of the organization. Comprehensive 
activities of enterprises regarding employees, society or the natural environment, having a consistent system of values on which all company's activities are based, provide the possibility of its stable and proper functioning (Zemigała, 2007; Ratajczak, 2014; Rokicki, 2016).

The European Commission defines social responsibility as an idea in which companies voluntarily incorporate social and environmental issues into their business activities and into relations with their stakeholder groups (Green Paper, 2001; Roome, 2009).

It should be mentioned that in addition to the definitions referred to above, in May 2010 at the ISO (International Standard Organization) plenary session, the first international standard of corporate social responsibility was adopted - ISO 26000, which was officially translated and presented in Poland in the second half of 2012 (Global Compact, 2010, Esty, Simmons, 2011). In its content, apart from the principles of social responsibility, a description of the basic seven CSR areas relating to: organizational order, human rights, relations with employees, the natural environment, market practices, consumer issues and social involvement and development was presented (Banerjee, 2011; Baran and Rokicki, 2015; Ratajczak, 2013).

Corporate social responsibility in Poland is a relatively little-known initiative and is not yet permanently implemented in the minds of Polish entrepreneurs, especially in the sphere of SMEs and local communities. Professional CSR tools, code of ethics, social reporting, audits and certification are mainly used by large enterprises (Gorecka and Rokicki, 2014; MCWilliams, 2001, Sethi, 1979, Reich, 2008).

The aim of the article is to present selected issues related to the implementation of CSR in the studied agribusiness enterprises from rural areas of the Mazowieckie voivodeship. The basic question about research is: is the CSR strategy implemented in polish agribusiness enterprises and what factors influence this?

\section{Materials and methods}

Research on the opinion of entrepreneurs on the concept of CSR, its scope and application of the principles of social responsibility were carried out at the turn of 2017 and 2018 and included 325 micro (0-9 people), small (10-49 employees) and medium (50-249 employees) agribusiness enterprises conducting economic activity in rural areas of the Mazowieckie voivodeship.

The research was carried out by means of a diagnostic survey, and the basic research tool was an electronic questionnaire addressed to the surveyed entities. The survey was sent to all agribusiness entities operating in the studied voivodeship - 325 questionnaires were fully completed correctly. The material obtained in this way was subjected to mathematical - statistical analysis. The arithmetic mean, $\mathrm{x} 2$ independence test, Chuprov convergence coefficient and C. Pearson coefficient (corrected and regular) were used.

Small companies dominated in the analysed sample - they accounted for $64.7 \%$, micro enterprises - $29.7 \%$, respectively, and medium enterprises - $5.6 \%$. Men owned $58.7 \%$ of analysed enterprises, and women $41.3 \%$ of business entities from the agribusiness sector. The structure of owners of the surveyed enterprises by their education was advantageous. The managers of $62 \%$ of companies had higher education - this is definitely a positive phenomenon considering the trend of migration of educated people from villages to large urban agglomerations. Over $32 \%$ of respondents had secondary education. The remaining subjects were characterized by primary education and accounted for about $6 \%$ of the respondents. 
Nearly $66 \%$ of the respondents were active in the industrial processing section, which is characteristic for small and medium-sized agribusiness companies on a national scale, especially in rural areas. Every fourth respondent dealt with wholesale and retail trade, which resulted from frequent localization of business entities in rural areas near large urban agglomerations (distribution and sale of offered goods), especially in the vicinity of Warsaw, Radom, Skierniewice, Ciechanow or Plock. The remaining two sections, agriculture and transport, accounted for around $10 \%$ in the structure of the surveyed entrepreneurs.

The largest number of studied enterprises (almost $56 \%$ ) functioned as natural persons conducting economic activity - this form is also the most common in the whole country in rural areas. In other cases, these entities were registered as limited liability companies, civil (every eleventh entity) and general partnerships (approximately $10 \%$ of the surveyed population).

\section{Research results and discussion}

The results of research carried out in small and medium-sized agribusiness companies in the Mazowieckie Voivodeship showed that almost $25 \%$ of entrepreneurs do not take actions in the field of CSR in their policy (Figure 1). Unfortunately, in the case of such business entities, we can talk about the attitude of resistance to CSR and related changes. Only every third respondent stated that activities are undertaken for the broadly understood environment and they are inscribed in the company's strategy. In the case of these enterprises, one can speak of a conscious attitude of social contribution and actions aimed at improving the quality of life of citizens. On the other hand, almost $38 \%$ of respondents declared taking steps of a CSR and prosocial character, but rather in an occasional way, if they were asked for it.

In order to determine the statistical independence between the education of the owners of the surveyed enterprises and having the CSR strategy, the $x 2$ independence test was carried out, which showed that the analysed variables are mutually dependent (Table 1). Activities for the broadly understood business environment were implemented primarily by owners with higher education and CSR steps, but without a strategy, were undertaken by entrepreneurs with secondary education. Practically, no elements of the CSR strategy existed in people with elementary education. It should also be emphasized that the calculated indices show a moderate strength of the relationship between the variables studied.

Statistical independence was also determined between the activity section and having a corporate social responsibility strategy (Table 2). The $x 2$ independence test carried out for this purpose showed that the variables under study are not mutually independent. In a wide range of CSR activities in the context of the company's environment, they were undertaken by small and medium-sized enterprises from the industrial processing sector as well as wholesale and retail trade. Prosocial steps were taken primarily by economic entities from the agricultural section, and in the smallest scope such activities were carried out by transport companies. The strength of the relationship between the analysed variables is relatively strong, as illustrated by the calculated coefficients. 
Source: authors' elaboration

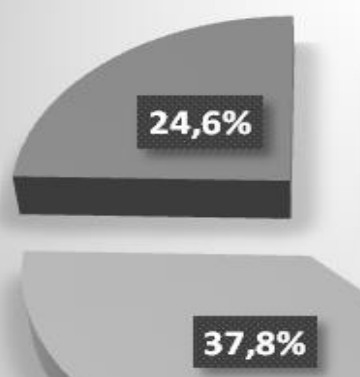

$37,8 \%$

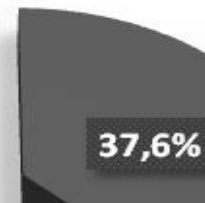

$37,6 \%$

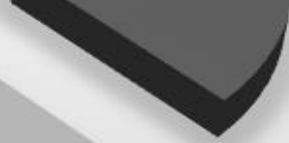

- yes, we are taking action in favor of the wider environment of the company

has not developed a strategy, but steps are being taken by a CSR and prosocial

not, does not exist in any form

Fig. 1. Possession of CSR strategy by surveyed agribusiness companies ( $\%$ )

Determination of statistical independence between surveyed business owners' education and possession of social responsibility strategy

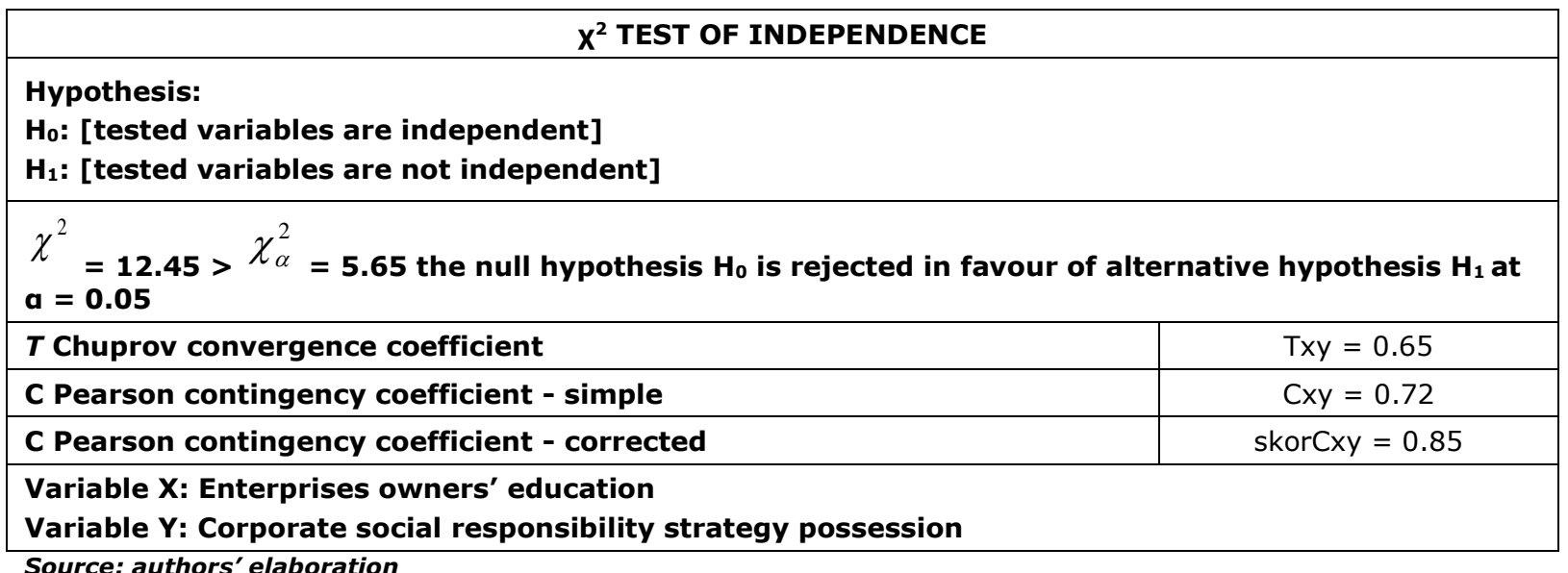

Determination of statistical independence between the section of activity (NACE) and possession of social responsibility strategy

\begin{tabular}{|c|c|}
\hline \multicolumn{2}{|c|}{$x^{2}$ TEST OF INDEPENDENCE } \\
\hline \multicolumn{2}{|l|}{$\begin{array}{l}\text { Hypothesis: } \\
\text { HO: [tested variables are independent] } \\
\text { H1: [tested variables are not independent] }\end{array}$} \\
\hline \multicolumn{2}{|c|}{$\begin{aligned} & \chi^{2}=23.77>\chi_{\alpha}^{2}=11.54 \text { the null hypothesis } \mathrm{HO} \text { is rejected in favour of alternative hypothesis } \mathrm{H1} \\
& \text { at } \mathrm{a}=\mathbf{0 . 0 5}\end{aligned}$} \\
\hline T Chuprov convergence coefficient & $\mathrm{Txy}=0.69$ \\
\hline C Pearson contingency coefficient - simple & $C x y=0.77$ \\
\hline C Pearson contingency coefficient - corrected & skorCxy $=0.87$ \\
\hline \multicolumn{2}{|c|}{$\begin{array}{l}\text { Variable X: Activity section (NACE) } \\
\text { Variable Y: Corporate social responsibility strategy possession }\end{array}$} \\
\hline
\end{tabular}

The validity of the above-mentioned independence test is demonstrated by the data on possession of a responsible business strategy according to the section of the economy. The analyses carried out show that activities in favor of the broadly understood business environment occurred mainly in industrial processing enterprises (over $72 \%$ of responses) and commercial companies (over half of indications). In turn, the steps of CSR character, but without the strategy 
developed, took place primarily in companies from the agricultural sector - about $44 \%$ of responses. It should also be noted that in the transport industry over $76 \%$ of the surveyed entrepreneurs do not have any CSR strategy in any form.

An important issue is also the possession of a CSR strategy according to the size of the enterprise. Only $9 \%$ of micro-enterprises had a strategy of responsible business, and about $13 \%$ of them took pro-social activities. A more positive trend was observed in the activity of small and medium-sized business entities - over $57 \%$ of surveyed business owners indicated possession of a formal CSR strategy, and about $38 \%$ undertook extensive activities to build social responsibility of their company, which is certainly very important, especially in the agribusiness sector in Poland. In this group of companies, only about $4 \%$ of respondents did not undertake any activities aimed at building a CSR strategy.

\section{Determination of statistical independence between the year of company establishment and social responsibility strategy possession}

\begin{tabular}{|c|c|}
\hline \multicolumn{2}{|c|}{ X2 TEST OF INDEPENDENCE } \\
\hline \multicolumn{2}{|l|}{$\begin{array}{l}\text { Hypothesis: } \\
\text { H0: [tested variables are independent] } \\
\text { H1: [tested variables are not independent] }\end{array}$} \\
\hline \multicolumn{2}{|c|}{$\begin{array}{l}\chi^{2}=\mathbf{1 7 . 8 9}>\chi_{\alpha}^{2}=\mathbf{5 . 5 6} \text { the null hypothesis } \mathrm{HO} \text { is rejected in favour of alternative hypothesis } \mathrm{H} 1 \\
\text { at } \mathrm{a}=\mathbf{0 . 0 5}\end{array}$} \\
\hline T Chuprov convergence coefficient & $\mathrm{Txy}=0.65$ \\
\hline C Pearson contingency coefficient - simple & Cxy $=0.71$ \\
\hline C Pearson contingency coefficient - corrected & skorCxy $=0.88$ \\
\hline \multicolumn{2}{|c|}{$\begin{array}{l}\text { Variable } X \text { : Year of company establishment } \\
\text { Variable } Y \text { : Corporate social responsibility strategy possession }\end{array}$} \\
\hline
\end{tabular}

Statistical independence was also examined between the company's year of establishment and possession of a social responsibility strategy (Table 3 ). Also in this case, the $x 2$ independence test showed that the variables studied are interdependent. The CSR strategy was mainly present in companies established in 1990-1999, and also before 1989. In contrast, in enterprises that had a shorter period of existence on the market, the frequency of occurrence of CSR strategy elements was much less frequent, especially in entities established after 2004. The coefficients calculated for this purpose show that the strength of dependence of these features was strongly moderate - the highest value was achieved by the corrected Pearson's contingency coefficient.

Very often it happens so that the implementation of CSR principles depends, to a large extent, on the attitude of the person managing the enterprise and those responsible for compliance with these principles in business practice. Over $27 \%$ of respondents confirmed that the company does not have a person responsible for activities related to social responsibility. Almost $60 \%$ of entrepreneurs declared that persons responsible for CSR activities also have a different scope of professional responsibilities or deal with these issues temporarily. The implementation and execution of these principles becomes an additional duty and may lead to discrepancies in their implementation in practice. It should also be emphasized that only $13 \%$ of the respondents confirmed that there is an independent position for CSR in the company and this person aims to prepare all elements related to the implementation of responsible business in the enterprise. 


\section{Conclusions}

If we take into account only the formal side of the CSR concept functioning in the surveyed agribusiness enterprises, it should be stated that the social responsibility in the organizational structure was not very visible because there were no people responsible for developing the CSR concept related to the subject of the activity and the company's specificity. Only every third respondent stated that actions are being taken for broadly understood environment and they are inscribed in the company's business strategy. In a wide range of CSR activities, in the aspect of the company's environment, they were undertaken by small and medium-sized enterprises from the industrial processing and wholesale and retail trade sectors. It is certainly disturbing that in the economic entities from the agricultural and transport industries, the activities in the field of responsible business were taken very rarely, or they were not there at all. In the agribusiness sector, these are very important issues and should be properly promoted and popularized.

Summarizing the above considerations, it should be stated that entrepreneurs in their companies must try to implement instruments of social responsibility policy, including by creating a uniform strategy in this area. In practice, declarations that are recorded and followed give a much greater guarantee of quality and inspire confidence among stakeholders.

The precisely defined scope of the CSR strategy and its form will also allow it to be adapted to the type of business activity conducted, especially in the agribusiness sector, which is crucial for the economy of each country. In this way, it will be easier to engage employees in such activities by showing key elements of socially responsible business and encouraging them to be active in this area. Certainly, the interest and tendency to implement CSR in Poland is improving every year, but much more attention should be paid to this in rural areas, as demonstrated by research in this field.

\section{Bibliography}

1. Baran, J., Rokicki, T. (2015). Productivity and Efficiency of US Metal Industry in 2006-2014, In Metal 2015: 24th International Conference on Metallurgy and Materials. Conference Proceedings. Ostrava: TANGER, 2015, pp. 1841-1846.

2. Carroll, A. (1974). Corporate Social Responsibility: its Managerial Impact and Implications. Journal of Business Research, Nr 2, pp. 75-90.

3. Esty, D., Simmons, p. (2011). The Green to Gold Business Playbook - How to Implement Sustainability Practices for Bottom Line Results in Every Business Function, Willey \& Sons, Hoboken, NJ.

4. Garriga, E., Mele, D. (2004). Corporate Social Responsibility Theories - Mapping the Territory, Journal of Business Ethics, Nr 53, pp. 51-68.

5. Gasparski, W., Lewicka-Strzalecka, A., Rok, B., Szulczewski, G. (2004). Odpowiedzialnosc spoleczna i etyka biznesu w polskim zyciu gospodarczym, Wstepny raport z badan (Social Responsibility and Business Ethics in Polish Business Life, Preliminary Research Report), Wydawnictwo IFiS PAN - Centrum Etyki Biznesu L. Kozminskiego, Warszawa, p. 18.

6. Gorecka, A., Rokicki, T. (2014). The Significacne of Transportation in Agribusiness Companies. CLC 2013: Carpathian Logistics Congress - Congress Proceedings, pp. 24-30.

7. Mądra-Sawicka M. (2016). Samofinansowanie dzialalnosci w przedsiebiorstwach rolniczych (Self-financing of Activities in Agricultural Enterprises), Finanse, Rynki Finansowe, Ubezpieczenia, Nr 4, Wydawnictwo SGGW, Warszawa, pp. 425-435.

8. McWilliams, A., Siegel, D. (2001). Corporate Social Responsibility - a Theory of the Firm Perspective, Academy of Management Review, Nr 26, pp. 117-130.

9. Promotion of the European Project for Corporate Social Responsibility, European Commission, Green Paper final version, 2001.

10. Ratajczak, M. (2013). Dzialania CSR wobec pracownikow na przykladzie przedsiebiorstw agrobiznesu z Warmii i Mazur (CSR Activities Towards Employees on the Example of Agribusiness Companies from Warmia and Mazury), Przeglad Organizacji, Nr 12, pp. 14-19, Warszawa.

11. Ratajczak, M. (2014). The Implementation of Selected Elements of the CSR Concept on the Example of Agribusiness Enterprises from Warmia and Mazury, Management, Vol. 18, Nr 1, pp. 109-123, Zielona Gora. 
12. Ratajczak, M., Woloszyn J., Stawicka, E. (2012). Społeczna odpowiedzialnosc malych i srednich przedsiebiorstw agrobiznesu z obszarow wiejskich (Social Responsibility of Small and Medium-sized Agribusiness Enterprises from Rural Areas), Wydawnictwo SGGW, Warszawa, pp. 26-27.

13. Reich, R. (2008). The Case Against Corporate Social Responsibility, Goldman School of Public Policy Working Papers, $\mathrm{nr} 3$.

14. Rokicki T., (2016). Sustainable Development in Energy Sector in the European Union Countries, Economic Science for Rural Development. Proceedings of the International Scientific Conference, No 43, pp. 108-116.

15. Roome, N. (2009). Company Strategies for Corporate Responsibility and Sustainability in an era of Fragmented Globalization, Challenges and practices, Stockholm, pp. 25-34.

16. Sethi, p. (1979). Dimensions of Corporate Social Responsibility, Californian Management Review, Nr 17 (3), pp. 57-65.

17. United Nations Global Compact: A New Era of Sustainability, UN Global Compact Accenture CEO Study, New York 2010.

18. Vogel, D. (2005). The Market for Virtue - the Potential and Limits of Corporate Social Responsibility, Washington: DC Brookings Institution Press, Washington.

19. Waddock S. (2008). Building a New Institutional Infrastructure for Corporate Responsibility, Academy of Management Perspectives, No 22 (3), pp. 87-107.

20. Willard, B. (2002). The Sustainability Advantage - Seven Business Case Benefits of a Triple Bottom Line, Gabriola Island: New Society Publishers.

21. Wysokinski, M., Dziwulski, M. (2013). Land as Main Production Factor on Dairy Farms in Poland. Economic Science for Rural Development: production and cooperation in agriculture / finance and taxes. Proceedings of the International Scientific Conference, Issue 30, pp. 128-133.

22. Zemigała, M. (2007). Spoleczna odpowiedzialnosc przedsiebiorstwa. Budowanie zdrowej, efektywnej organizacji (Corporate Social Responsibility. Building a Healthy, Effective Organization), Oficyna Wolters Kluwer, Krakow, p. 99. 